\title{
Perspektif Moral Penegakan Hukum yang Baik
}

\author{
Kusnu Goesniadhie S. \\ Fakultas Hukum Universitas Wisnuwardhana Malang \\ J1. Danau Sertani No. 99 Malang \\ unidha@telkom.net
}

\begin{abstract}
This research discusses about some rules related with the law's establishment which is not only related with the body of law but also related with the nation's institution, such as the compiling process to make a law's constitution in Legislative institution and the protection for the public interest by the Executive institution. This research will excavate the good concept of law enforcement as the direct derivation of good governance concept. This research uses the concept of academic thinking and applies a good rule as has said in the frame of law's comprehensibility. This is a theoretical explorative research. It uses the combination of normative method as well as theoretical method as the analysis method. The conclusion of this research is that good law enforcement needs an organized application in its process in order to gain the aimed goal which covers the actualization of value system that becomes the basis of attitude preference in the law enforcement, which is also aimed to the law's intention.
\end{abstract}

Key words : Legal moral, law enforcement, good governance.

\begin{abstract}
Abstrak
Penelitian ini membahas beberapa aturan mengenai penegakan hukum yang tidak hanya berkaitan dengan badan-badan hukum, tetapi juga lembaga-lembaga negara seperti adanya penyusunan UU di DPR (legislatif) dan perlindungan bagi kepentingan umum oleh lembaga eksekutif (eksekutif). Penelitian ini akan menggali konsep penegakan hukum yang baik sebagai korivasi langsung dari konsep good governance. Penelitian ini akan menggunakan konsep pemikiran teori akademis serta menerapkan aturan yang baik seperti yang diterapkan dalam kerangka kejelasan hukum. Penelitian ini bersifat eksploratif teoritis. Metode pengkajian yang digunakan adalah kombinasi antara metode normatif dan teoritis. Kesimpulan penelitian ini bahwa penegakan hukum yang baik memerlukan pelaksanaan yang terarah pada proses pencapaian sasaran yang meliputi aktualisasi tata nilai yang melandasi dan menjadi acuan perilaku proses penegakan hukum, yang tertuju pada pencapaian tujuan hukum.
\end{abstract}

Kata kunci : Hukum moral, penegakan hukum, tata kelola yang baik. 


\section{Pendahuluan}

Dalam perjalanan waktu panjang sejarah bangsa Indonesia, negara dan hukum yang dicita-citakan, seringkali tidak berdaya untuk membantah dan menahan arus kepentingan sebagian kelompok orang yang pada gilirannya mengorbankan hakhak rakyat banyak, yang pada hakikatnya mengorbankan misi suci hukum itu sendiri. Hukum dalam banyak hal, seringkali bermetamorfosis menjadi "legally institution" the arbitrariness dan "punishment institution" seeker of justice. Implikasi dari "fallacy" hukum tersebut adalah porak porandanya sistem hukum nasional.

Penegakan hukum adalah kegiatan menyerasikan hubungan nilai-nilai yang terjabarkan dalam kaidah-kaidah, pandangan-pandangan yang mantap dan mengejawantahkannya dalam sikap, tindak sebagai serangakaian penjabaran nilai tahap akhir untuk menciptakan kedamaian pergaulan hidup. ${ }^{1}$ Penegakan hukum hanya dapat terlaksana apabila berbagai dimensi kehidupan hukum selalu menjaga harmonisasi (keselarasan, keseimbangan dan keserasian) antara moralitas sosial, moralitas kelembagaan dan moralitas sipil warga negara yang didasarkan pada nilainilai aktual di dalam masyarakat. Dengan demikian kebersamaan sangat dibutuhkan tidak hanya untuk membuat rambu-rambu pergaulan nasional, melainkan juga penegakannya. $^{2}$

Dalam kerangka demikian keberadaannya terlihat sebagai tuntutan yang telah melahirkan code of conduct. Standar-standar dalam code of conduct dapat dijadikan sarana untuk menentukan apakah telah terjadi malpraktek profesional atau tidak. Dapat dikatakan telah terjadi malpraktek apabila seorang profesional dalam menjalankan tugas dan kewajibannya telah melakukan tindakan yang tidak profesional di bawah standar atau sub-standard profesinya, menimbulkan kerugian (damage) terhadap orang lain sebagai akibat perbuatannya. ${ }^{3}$

Secara konseptual merupakan malpraktik apabila menegakkan hukum dengan spirit yang sudah tidak sesuai dengan perkembangan zaman. Mesti dibedakan antara spirit undang-undang (legal spirit) seperti tersurat dan tersirat dalam konsiderans dan penjelasan umum peraturan perundang-undangan dengan spirit penegakan

\footnotetext{
${ }^{1}$ Soerjono Soekanto, Beberapa Permasalahan Hukum Dalam Kerangka Pembangunan Di Indonesia, UI-Press, Jakarta, 1983, hlm.3.

${ }^{2}$ Mardjono Reksodiputro, "Reformasi Hukum di Indonesia", Seminar Hukum Nasional Ke VII, BPHN Departemen Kehakiman dan HAM, 1999, hlm.73-87.

${ }^{3}$ Ibid.
} 
hukum (spirit of enforcement) yang menurut Pasal 24 ayat (1) UUD 1945, peradilan harus selalu diselenggarakan guna menegakkan hukum dan keadilan.

Dalam Code of Conduct for Law Enforcement Officials, Article 1, menentukan "law enforcement officials shall at all times fulfil the duty imposed upon them by law, by serving the community and by protecting all persons against illegal acts, consistent with the high degree of responsibility required by their profession". ${ }^{4}$ Para petugas penegak hukum sepanjang waktu harus memenuhi kewajiban yang dibebankan kepadanya oleh hukum, dengan melayani masyarakat dan dengan melindungi semua orang dari perbuatan-perbuatan yang tidak sah, konsisten dengan tingkat pertanggungjawaban yang tinggi yang dipersyaratkan oleh profesi mereka.

Pokok dan fokus pembahasan dalam studi ini mencoba menggali konsep pemikiran teoritis-akademis, mengaplikasikan konsep good governance dipahami dan diaplikasikan sebagai kerangka penegakan hukum. Dengan demikian secara teoritis dalam studi ini akan dikenal konsep "good law enforcement governance", dalam pengertian kerangka konsep "penegakan hukum yang baik" derivasi langsung dari konsep good governance.

\section{Rumusan Masalah}

Bagaimanakah konsep penegakan hukum yang baik sebagai derivasi langsung dari konsep good governance?

\section{Tujuan Penelitian}

Untuk mengetahui secara mendalam bagaimana konsep penegakan hukum yang baik sebagai derivasi langsung dari konsep good governance.

\section{Metode Penelitian}

Metode dimaksud adalah cara-cara untuk memperoleh informasi atau bahan yang diperlukan dalam studi ini. Metodologi penelitian ilmiah adalah "... the process, principles and prodecures by which approach problems and seek answers. In the social sciene, the term applies to how to conduct research". ${ }^{5}$ Metodologi pada hakikatnya berusaha

\footnotetext{
${ }^{4}$ Code of Conduct for Law Enforcement Officials, Adopted by General Assembly Resolution 34/169 of 17 December 1979. Office of the United Nation High Commissioner for Human Right, http:// www2.ohchr.org/ english/law/ codeofconduct.htm.

${ }^{5}$ Robert Bogdan and Steven J. Taylor, Introduction to Qualitative Research Methods, John Wiley \& Sons, New York, 1975, hlm. 14
} 
untuk memberikan pedoman tentang cara-cara seorang ilmuwan untuk mempelajari, menganalisa dan memahami lingkungan-lingkungan yang dihadapinya. Sedangkan yang dimaksud dengan penelitian ialah usaha untuk menghimpun serta menemukan hubungan-hubungan yang ada antara fakta-fakta yang diamati secara seksama. Apabila dikaitkan dengan ilmu hukum, maka penelitian ilmiah merupakan sarana untuk dapat mengembangkan ilmu hukum. Ilmu hukum mencakup kegiatan mengadakan analisa dan konstruksi secara sistematis, konsisten dan tepat, terhadap gejala atau peristiwa-peristiwa hukum dalam perkembangan dan perubahan sosial di dalam masyarakat.

Studi ini merupakan penelitian hukum yang bersifat eksploratif-teoritis. Menggali konsep pemikiran teoritis-akademis, mengaplikasikan konsep good governance dipahami dan diaplikasikan sebagai kerangka penegakan hukum. Dengan demikian secara teoritis akan dikenal konsep "good law enforcement governance", dalam pengertian kerangka konsep "penegakan hukum yang baik" derivasi langsung dari konsep good governance. Metode pengkajian yang digunakan adalah kombinasi antara metode kajian normatif dan metode kajian teoritis, dengan bantuan teori-teori yang relevan untuk mengantar pada kegiatan penegakan hukum yang baik.

\section{Hasil dan Pembahasan}

Untuk sampai pada pembahasan tentang penegakan hukum yang baik, kiranya perlu uraian singkat mengenai tingkat pemahaman masyarakat terhadap hukum.

\section{Hukum dalam Masyarakat}

Banyak pakar berpendapat bahwa hukum merupakan bagian yang penting dalam kehidupan manusia terutama kehidupan bernegara. Dalam pembicaraan sehari-hari, media cetak, media elektronik, maupun dalam berbagai kesempatan, seringkali dilontarkan berbagai macam bentuk ungkapan yang mengatasnamakan hukum, baik bagi mereka yang berlindung atas nama hukum, maupun pihak-pihak yang menghujat hukum. Konsep hukum sangat luas, meskipun dalam berbagai rumusan dan tulisan telah merujuk dan mengutip pendapat para sarjana maupun filsuf yang mencoba untuk memberikan suatu definisi atau bentuk-bentuk pemahaman mengenai hukum. Dalam praktik tidak jarang dijumpai kesalahpahaman dan salah penafsiran, bahkan telah memberikan penafsiran baru terhadap hukum itu sendiri. 
Pada dasarnya, suatu hukum yang baik adalah hukum yang mampu mengakomodasi dan membagi keadilan pada orang-orang yang akan diaturnya. Kaitan yang erat antara hukum dan nilai-nilai sosial budaya masyarakat ternyata bahwa hukum yang baik adalah hukum yang mencerminkan nilai-nilai yang hidup dalam masyarakat. Namun sudah sejak lama orang mempunyai keraguan atas hukum yang dibuat manusia. Enam ratus tahun sebelum Masehi, Anarchasis menulis bahwa hukum seringkali berlaku sebagai sarang laba-laba, yang hanya menangkap "...the weak and the poor, but easily be broken by the mighty and rich...". Lima ratus tahun sebelum Masehi Trasymachus ketika berdebat dengan Socrates mengenai keadilan, “... hukum, tidak lain kecuali kepentingan mereka yang kuat”. Pandangan miring tentang hukum dikemukakan pula oleh Machiavelli, “... hukum menjadi wahana bagi kepentingan yang memiliki kekuasaan, sementara bagi kaum tanpa kekuasaan, hukum menjadi tidak berdaya untuk membelanya". ${ }^{6}$ Demikian halnya, lebih dari empat ratus tahun sebelum Masehi Plato mengemukakan bahwa "laws are spider webs; they hold the weak and delicated who are caught in their meshes but are torn in pieces by the rich and powerful", hukum adalah jaring laba-laba yang hanya mampu menjerat yang lemah tetapi akan robek jika menjerat yang kaya dan kuat. Di sisi lain, kaum Sofist berpendapat bahwa "justice is the interest of the stronger", bahwa hukum merupakan hak dari penguasa. Dalam 'The Second Treatise of Civil Government', John Locke telah memperingatkan bahwa "whereever law ends, tyranny begins". ${ }^{7}$

Dalam hubungan ini, maka terlihat bahwa hukum yang berlaku mencerminkan ideologi, kepedulian dan keterikatan pemerintah pada rakyatnya, tidak semata-mata merupakan hukum yang diinginkan rakyat untuk mengatur mereka. Hukum yang berpihak pada rakyat, yang memperhatikan keadilan sosial, yang mencerminkan perlindungan hak asasi manusia, seperti tercantum dalam konstitusi UUD 1945. Hukum bukan hanya merupakan pedoman berperilaku bagi rakyat, tetapi juga bagi para pejabat pemerintahan dan seluruh penyelenggara kenegaraan.

Dalam Black's Law Dictionary, Bryan A. Garner memberikan definisi hukum sebagai: "The regime that orders human activies and relations through systematic application of the force of politically organized society, or trough a pressure, backed by force, in such a society; the legal system (respect and obey the law). The aggregate of legislation, judicial

\footnotetext{
${ }^{6}$ Diane Collinson, Fifty Major Philosophers, (terj. Ilza mudin Ma'mur dan Mufti Ali, Lima Puluh Filosof Dunia Yang Menggerakekan), Raja Grafindo, Jakarta, 2001, hlm. 61-63.

${ }^{7}$ John Locke, The Secon Treaties of Government, Stuttgart, Reclam, 1980, hlm. 9
} 
precedents, and accepted legal principles; the body of judicial and administrative action (the law of land). The judicial and administrative process, legal action and proceedings (when settlement negotiations failed, they submitted their dispute to the law)...".

Melalui uraian singkat di atas, maka secara umum dapat dikatakan bahwa manusia pada dasarnya secara berkesinambungan berupaya untuk memberikan pemahaman tentang hukum, setidaknya telah memahami tentang konsep hukum. Banyak pakar yang berusaha untuk memberikan arti hukum, tetapi tidak jarang arti hukum tersebut dikatakan masih bersifat mendekati sempurna. L.J. van Apeldoorn mengkalimatkan, tidak mungkin memberikan definisi tentang hukum yang sungguhsungguh dapat memadai kenyataan. ${ }^{9}$ Seperti kata Immanuel Kant, bahwa para jurist masih mencari suatu definisi bagi pengertian mereka tentang hukum (noch suchen die juristen eine definition zu ihrem begriffe von recht). Demikian pula Dennis Lloyd, dalam L.B. Curzon (1979), "... although 'much juristic ink' has been used in an attemp to provide 'a universally acceptable definition of law' there is little sign of the objective having been attained". ${ }^{10}$ Walaupun sejak beribu tahun orang sibuk mencari sesuatu definisi tentang hukum, namun belum pernah terdapat sesuatu yang memuaskan. Kesulitannya terletak pada kata-kata yang dipergunakan dalam mengartikulasikan hukum yang pada akhirnya justru membatasi ruang gerak pemikiran tentang hukum itu sendiri. ${ }^{11}$

Para sarjana terus mencoba untuk memberikan arti hukum, tetapi hukum itu sendiri tetap hidup meskipun tanpa diberikan arti maupun definisi. Terhadap terminologi hukum, masyarakat pun sudah memberikan suatu pandangan tertentu. Namun keadaan demikian ini tidak dapat dikatakan sebagai pernyataan untuk suatu alasan pemaaf bagi masyarakat maupun para pejabat hukum untuk mengabaikan atau tidak mengetahui arti hukum. Hukum bukan sesuatu yang mistik seperti di zaman purbakala, melainkan sesuatu yang rasional yang dijangkau oleh setiap orang yang hidup dalam masyarakat secara sadar. Di sisi lain, hukum tidak dapat diberikan sembarang arti, atau diberikan arti sesuai selera oleh sembarang orang, terlebih disalahgunakan.

Hukum menjadi landasan dalam berperilaku, bukan hanya bagi masyarakat, tetapi juga bagi para pejabat pemerintahan di badan-badan legislatif, eksekutif atau

\footnotetext{
${ }^{8}$ Bryan A. Garner et.al., Black's Law Dictionary, St. Paul Minn, West Group, 1999, hlm.889.

${ }^{9}$ L.J. van Apeldoorn, Pengantar Imu Hukum, Pradnya Paramita, Jakarta, 1983, hlm.13.

${ }^{10}$ L.B. Curzon, Jurisprudence, W \& E Handbook, 1979, hlm. 24-25.

${ }^{11}$ L.J. van Apeldoorn, Loc.Cit.
} 
administratif dan badan-badan yudisial. Walau demikian, hukum dimaksud adalah hukum yang memang benar-benar diciptakan melalui proses yang benar dan sesuai dengan aspirasi masyarakat, dengan mengacu pada kepentingan masyarakat dan keadilan sosial. Seperti dikalimatkan oleh Kusumohamidjojo (1999), tanpa adanya hukum yang berkeadilan, baik yang dibuat oleh badan-badan legislatif, eksekutif maupun yudisial, sulit diharapkan bahwa hukum akan diterima dan dijadikan panutan. Dalam hubungan ini, baik dari komponen-komponen hukum, maupun dari faktor-faktor yang memandu orientasi masya-rakat, apalagi dari penghormatan terhadap prinsip keadilan bagi penerapan hukum itu nyatalah bahwa lembagalembaga kenegaraan yang menetapkan norma hukum, melaksanakan-nya, maupun yang menindak pelanggaran terhadapnya dan lebih lagi para pejabat yang menyandang jabatan lembaga-lem-baga tersebut, memainkan peranan yang besar. ${ }^{12}$

Dari uraian singkat tentang hukum dalam kehidupan masyarakat di atas, pada akhirnya kita akan berbicara mengenai manusia dalam mencoba untuk mengaplikasikan hukum, dan refleksi dari para pejabat hukum yang terjadi di badanbadan legislatif, eksekutif atau administratif dan badan-badan yudisial, serta akibat yang ditimbulkannya.

\section{Konsep Penegakan Hukum yang Baik}

Dalam banyak kepustakaan dan berbagai wacana ilmu hukum dan pemerintahan, istilah good governance banyak diangkat ke dalam pembahasan. Seolah hendak mendesak istilah clean government yang sebelumnya lebih banyak dikenal dan mewarnai pembahasan dalam kepustakaan. Institute On Governance dalam Principles for Good Governance in the 21st Century membedakan istilah government dan governance, bahwa governance is not synonymous with government. This confusion of terms can have unfortunate consequences. A public policy issue where the heart of the matter is a problem of governance becomes defined implicitly as a problem of "government", with the corollary that the onus for "fixing" it necessarily rests with government. ${ }^{13}$ Di samping itu, Institute On Governance memberikan definisi: "Governance comprises the institutions, processes and

${ }^{12}$ Budiono Kusumohamidjojo, Ketertiban Yang Adil Problematik Filsafat Hukum, Gramedia Widiasarana Indonesia, Jakarta, 1999. hlm. 157-158.

${ }^{13}$ John Graham and Bruce Amos and Tim Plumptre, Institute On Governance (IOG: 2003), Canada, dalam Principles for Good Governance in the 21st Century, Web. http://www.iog.ca/publications/policy 
conventions in a society which determine how power is exercised, how important decisions affecting society are made and how various interests are accorded a place in such decisions". ${ }^{14}$

Kemudian Commission on Global Governance (CGG: 1995), memberikan konsep: Governance is the sum of the many ways individuals and institutions, public and private, manage their common affairs. It is a continuing process through which conflicting or diverse interests may be accommodated and co-operative action may be taken. It includes formal institutions and regimes empowered to enforce compliance, as well as informal arrangements that people and institutions either have agreed to or perceive to be in their interest. ${ }^{15}$

Dalam 'Clean Government and Public Financial Accountability', Vinod Sahgal and Deepa Chakrapani (2000), mengajukan suatu konsep, bahwa: The first pillar of the Comprehensive Development Framework (CDF) calls for good and clean government. The CDF assumes that clean government promotes good governance. But good governance requires at minimum four elements: effective public financial accountability relationships between a country's governing bodies and its executive management, transparent decisionmaking, stakeholders participation, and ethical practices. ${ }^{16}$

Dalam 'Sustainability and good governance: Monitoring participation and process as well as outcomes' (2002), Julia Porter memberikan definisi: “Governance encompasses not just government, but also the private sector and civil society (individuals and groups) and the systems, procedures and processes in place for planning, management and decisionmaking". ${ }^{17}$ Di sisi lain, dalam Black's Law Dictionary, government diberikan definisi antara lain sebagai "... an organization through which a body of people exercise political authority; the machinery by which sovereign power is expressed...". 18

Dari pengertian di atas, terlihat tidak ada perbedaan arti antara apa yang disebut government yang hakikatnya harus bersih dan apa yang disebut governance yang hakikatnya harus 'baik'. Keduanya sama-sama merujuk pada arti pemerintah atau pemerintahan. Pemerintah atau pemerintahan, pada dasarnya merupakan suatu struktur lembaga formal menyelenggarakan tugas keseharian negara.

Dengan mendasarkan pada pengertian di atas, istilah governance pada dasarnya menunjuk pada tindakan, fakta, atau perilaku governing, yakni mengarahkan atau

${ }^{14}$ Ibid.

${ }^{15}$ Ibid.

${ }^{16}$ Vinod Sahgal, and Deepa Chakrapani, Clean Government and Public Financial Accountability, Washington, D.C., The World Bank, 2000, http:/ / wmw.worldbank.org/ html/ oed.

${ }^{17}$ Julia Porter, Sustainability and good governance: Monitoring participation and process as well as outcomes, 2002, Website, http:/ / www.porteradelaide/

${ }^{18}$ Bryan A. Garner et.al., Op.Cit., hlm.703. 
mengendalikan atau mempengaruhi masalah publik dalam suatu negara. Makna good governance sebagai tindakan atau tingkah-laku yang didasarkan pada nilai-nilai, dan yang bersifat mengarahkan, mengendalikan atau mempengaruhi masalah publik untuk mewujudkan nilai-nilai itu di dalam tindakan dan kehidupan keseharian.

Konsep good governance banyak dikembangkan dalam berbagai tulisan oleh para pakar dengan masing-masing argumentasi dan justifikasi, sehingga dikatakan sebagai a rather confusing variety of catchword; yang oleh Harkristuti dikatakan sebagai suatu konsep yang 'has come to mean too many different things. Demikian halnya menurut Europa Union Commission (1997), bahwa the term governance is a very versatile one, dengan memberikan definisi governance, sebagai:

"It is used in connection with several contemporary social sciences, especially economics and political science. It originates from the need of economics (as regards corporate governance) and political science (as regards State governance) for an all-embracing concept capable of conveying diverse meanings not covered by the traditional term "government". Referring to the exercise of power overall, the term "governance", in both corporate and State contexts, embraces action by executive bodies, assemblies (e.g. national parliaments) and judicial bodies (e.g. national courts and tribunals)" ${ }^{19}$

Dalam hal konsep good governance dipahami dan diterapkan sebagai kerangka penegakan hukum yang menjadi pokok dan fokus pembahasan dalam studi ini, maka secara teoritis akan dikenal konsep good law enforcement governance, dalam pengertian kerangka konsep "penegakan hukum yang baik" derivasi langsung dari good governance. Dengan demikian, "penegakan hukum yang baik" lebih mengacu pada the manner, kinerja atau gaya moral-legal pelaksanaannya.

\section{Gaya Moral}

Hukum bersifat institusional, moralitas bersifat kontroversial dan personal. Hukum bersifat otoriter, mengatasi masalah dengan tindakan otoriter pula. Sedangkan moralitas berbeda dan mandiri, dalam arti moralitas selalu terbuka terhadap adu argumentasi untuk mencapai kata-kata yang sama. Hukum bersifat heterogen yang mengikat kita tanpa kecuali, sedangkan moralitas bersifat otonomi yang mengikat kita dengan keputusan dan keinginan kita sendiri.

Dalam Kamus Filsafat (1995), istilah moral dan etika (ethics) mempunyai pengertian yang sama, meskipun asal kata berbeda. Moral berasal dari bahasa Latin

\footnotetext{
${ }^{19}$ Europa Union International Commission, Web. http:/ / www.europa.eu.int/comm/ governance/
} 
mores, sedangkan etika dari bahasa Yunani ethos. Keduanya mempunyai pengertian the customs, yang berkaitan dengan aktivitas manusia yang dipandang baik atau tindakan yang benar, adil dan wajar. ${ }^{20}$ Dalam Encyclopedia International (1967), ethics diartikan sebagai "branch of philosophy concerned with conduct, the determination of good, and of right and wrong" ${ }^{21}$ Dalam New Webster Dictionary of the English Language (1970), ethics juga diartikan sebagai "the science which treats of the nature and grounds of moral obligation; moral philosophy which teaches men their duty and the reasons of it; the science of duty". ${ }^{22}$

Dalam Black's Law Dictionary (1999), 'moral absolutism' diartikan "the view that a person's action can always properly be seen as right or wrong, regardless of the situation or the consequences". Sedangkan "moral obligation" diartikan "a duty that is based only on one's conscience and that is not legally enforceable"; dalam hukum kontrak, "moral obligation may support a promise in the absence of traditional consideration, but only if the promisor has previously received some actual benefit from the promisee". Istilah 'ethical' diartikan "of or relating to moral obligations that one person owes another". Sedang 'legal ethics' diartikan "the standards of minimally acceptable conduct within the legal profession, involving the duties that its members owe one anbother, their clients, and the courts"; yang dimuat dalam Code of Professional Responsibility atau Code of Professional Conduct, sebagai "a set of ethical guidelines for lawyers, organized in the form of canons, disciplinary rules, and ethical considerations". ${ }^{23}$

Dalam 'teori perkembangan moral' (1997), perkataan moralis diartikan dengan ajaran kesusilaan, tabiat atau kelakuan. Moralitas berarti hal mengenai kesusilaan, sedangkan etika merupakan suatu ilmu yang membicarakan tentang perilaku manusia, perbuatan manusia yang baik dan yang buruk (ethics the study and phylosophy of human conduct with emphasis on the determination of right and wrong one of the normative sciences). Untuk membedakan kedua pengertian tersebut, dikenal dengan kata moral untuk menunjukkan perbuatan (moral act), sedangkan penyelidikan tentang moral sering diungkapkan sebagai ethical code. Etika lebih bersifat teori, sedangkan moral lebih menunjukkan praktek. ${ }^{24}$

Dalam hukum, terdapat suatu moralitas hukum yang spesifik, yang terdiri atas pencerminan pendapat-pendapat moral yang terdapat dalam masyarakat pada

\footnotetext{
${ }^{20}$ Yuliani Liputo, (ed.), Kamus Filsafat, Remaja Rosdakarya, Bandung,1995, hlm. 100-101.

${ }^{21}$ Encyclopedia International, Grolier Incorporated, New York, 1967, (6), hlm. 543.

${ }^{22}$ New Webster Dictionary of the English Language, Grolier Incorporated, New York, 1970, hlm. 300.

${ }^{23}$ Bryan A. Garner, Op. Cit., hlm. 1025.

${ }^{24}$ Burhanuddin, Etika Individual Pola Dasar Filsafat Moral, Rineka Cipta, Jakarta, 1997, hlm. 37.
} 
umumnya dan yang dikembangkan dalam praktek di bidang hukum dan yang terikat dalam lembaga-lembaga dan ajaran-ajaran hukum. Moralitas hukum ini merupakan bidang khusus para ahli hukum dan para sarjana hukum. Seringkali moralitas ini harus dilindungi terhadap pendapat mayoritas dan terhadap kepentingankepentingan politik dan sosial yang penting, misalnya, asas proses hukum yang wajar dalam pengadilan-pengadilan terhadap intervensi politik.

A pabila seperti uraian di atas pengertiannya, maka good law enforcement governance dalam studi ini dapat diterjemahkan sebagai seni atau gaya moral penegakan hukum yang baik. Dengan demikian yang dimaksudkan dengan "baik" dalam istilah "penegakan hukum yang baik", lebih memerlukan suatu butir-butir moral-legal dalam pelaksanaannya.

\section{Gaya Moral Penegakan Hukum yang Baik}

Kunci utama dalam memahami penegakan hukum yang baik (good law enforcement governance), adalah pemahaman atas prinsip-prinsip di dalamnya. Bertolak dari prinsip-prinsip penegakan hukum yang baik, akan dapat diperoleh tolok-ukur kinerja suatu penegakan hukum. Baik dan tidak baiknya penyelenggaraan penegakan hukum, dapat dinilai apabila pelaksanaannya telah bersinggungan dengan semua unsur prinsip-prinsip penegakan hukum yang baik, mengacu pada prinsip-prinsip demokrasi dengan elemen-elemennya, seperti legitimasi, akuntabilitas, perlindungan hak asasi manusia, kebebasan, transparansi, pembagian kekuasaan dan kontrol masyarakat. Oleh karena itu, suatu pelaksanaan penegakan hukum dapat disebut bergaya moral baik, apabila pelaksanaannya memenuhi elemen-elemen prinsip demokrasi tersebut.

Di antara prinsip-prinsip demokrasi dengan elemen-elemennya tersebut, empat prinsip di antaranya merupakan prasyarat utama yang saling terkait satu sama lain. Dengan kata lain, suatu pelaksanaan penegakan hukum dapat disebut bergaya moral baik, sekurang--kurangnya memenuhi empat syarat yang meliputi legitimasi, akuntabilitas, transparansi dan partisipasi. Pertama, penegakan hukum itu berlegitimasi atau taat asas, sehingga kekurangan dan kelebihannya akan dapat terprediksikan sebelumnya (predictable). Kedua, pelaksana penegakan hukum dapat dimintai pertanggungjawaban oleh masyarakat (accountable). Ketiga, prosesnya tidak dilakukan secara sembunyi-sembunyi yang dapat mengindikasikan adanya kolusi 
(transparency). Keempat, prosesnya terbuka untuk mengakomodasi opini kritis masyarakat (participated).

Keempat prasyarat tersebut tidak berdiri sendiri-sendiri, yang satu lepas dari yang lain. Predictability akan menentukan apakah suatu penegakan hukum, secara kolektif oleh suatu institusi, badan atau organisasi dengan kualitas birokrasinya masing-masing, atau secara individual oleh seseorang pejabat, telah dilaksanakan secara rasional, dan secara objektif sebagai bagian dari suatu sistem normatif yang telah dibangun. Dengan demikian benar-benar dapat dimintai pertanggungjawabannya.

Partisipasi masyarakat hanya dapat dipenuhi apabila sesuatu hal sampai batas tertentu telah dilaksanakan secara transparan. Sementara itu, mustahil norma accountability dapat direalisasi apabila kesempatan masyarakat untuk berpartisipasi tidak dibuka. Begitu halnya, norma transparansi tidak ada gunanya, bila hal itu tidak dimaksudkan untuk memungkinkan partisipasi dan permintaan akuntabilitas masyarakat. Partisipasi masyarakat tidak dapat terlaksana tanpa adanya transparansi. Akuntabilitas sulit terlaksana tanpa pemantauan dan partisipasi masyarakat dalam proses penegakan hukum. Ketidakjelasan dan ketidaktransparanan dalam proses penegakan hukum, membuat masyarakat selalu diliputi oleh berbagai pertanyaan, apakah memang benar bahwa kepentingan masyarakat selalu diprioritaskan. Untuk itulah kemampuan masyarakat harus diperkuat (empowering), kepercayaan masyarakat harus meningkat dan kesempatan masyarakat untuk berpartisipasi ditingkatkan. ${ }^{25}$

Dengan demikian membangun "penegakan hukum yang baik" sangat ditentukan oleh sikap dan perilaku para pejabat penegak hukum. Kejujuran adalah hal yang paling penting untuk dikembangkan dalam pembinaan sumber daya insani, karena kejujuran tidak ada modulnya. Kejujuran sangat dipengaruhi oleh keimanan dan integritas seseorang. Sebagai konsekuensi, pemerintah dengan sendirinya dituntut untuk meningkatkan kemampuan sumber daya insaninya sesuai dengan bidang tugasnya, kesejahteraannya, termasuk menentukan sikap dan perilakunya, agar mampu berpikir dengan baik dan benar.

${ }^{25}$ Soetandyo Wignjosoebroto, 'Hukum dan Moral Pemerintahan yang Baik', Jurnal Analisis Hukum 2002, Jangan Tunggu Langit Runtuh, Jakarta, hukumonline.com. 


\section{Implementasi Gaya Moral Penegakan Hukum yang Baik}

Penegakan hukum dalam definisinya yang luas, tidak hanya berkenaan dengan apa yang dilakukan para pejabat di wilayah yudisial semata, tetapi juga yang berlangsung di wilayah eksekutif, administrasi dan legislatif. Maka, wacana tentang syarat gaya moral pelaksanaan penegakan hukum yang baik, dimasukkan pula ke dalam proses bagaimana hukum itu dibentuk dan ditegakkan.

Pentingnya memahami penegakan hukum yang baik, dengan hak dan kewajiban yang dimiliki agar masyarakat mengetahui bahwa tolok-ukur yang diperlukan guna menilai kinerja para pejabat penegakan hukum itu ada, kemudian didayagunakan secara efektif melaksanakan kontrol sosial secara optimal, sehingga dapat diharapkan kualitas keputusan-keputusan para pejabat penegak hukum akan terjaga. Tingginya kualitas keputusan-keputusan para pejabat penegak hukum yang tertengarai memenuhi tolok-ukur predictability, accountability, transparency dan widely participated, akan mengindikasikan tingginya kadar demokrasi di dalam kehidupan bermasyarakat, berbangsa dan bernegara. ${ }^{26}$

Merupakan tuntutan dalam kehidupan hukum yang demokratis dan berwawasan kemasyarakatan untuk memberikan tolok-ukur setiap proses penegakan hukum oleh para pejabat yang berwenang, atas dasar kriteria mengenai gaya moral pelaksanaannya. Para pejabat penegakan hukum dan anggota masyarakat yang berkepentingan mesti sama-sama mengetahui kriteria untuk memberikan tolok-ukur ada-tidaknya penegakan hukum yang baik dalam praktek-praktek penegakan hukum yang akan berdampak pada kehidupan mereka.

Dengan memahami secara baik seluk-beluk dan liku-liku penegakan hukum yang baik, para penegak hukum dan para pejabat pemerintahan akan berhati-hati dalam bertindak guna menjaga kualitas moral-politik dan moral-legal keputusankeputusannya. Sementara itu, dengan mengetahui apa yang dimaksud dengan penegakan hukum yang baik, masyarakat pun akan dapat memberikan tolok-ukur dan menilai apakah badan legislatif, baik di pusat maupun di daerah, telah menguasai dan mampu melaksanakan gaya moral penegakan hukum yang baik atau belum. Masyarakat akan dapat menilai kepatuhan anggota-anggota badan legislatif pada ketentuan-ketentuan yang ada mengenai mekanisme dan prosedur yang telah ditetapkan demi terjaganya sistem hukum nasional. Kepatuhan pada mekanisme 
dan prosedur serta sistem yang ada, pada gilirannya akan menjamin terpenuhinya tuntutan predictability dan accountability.

Dengan mengetahui apa yang dimaksud dengan penegakan hukum yang baik, masyarakat akan dapat mengamati dan memberikan tolok-ukur apakah para pelaksana penegakan hukum sebagai fungsionaris dalam suatu proses peradilan, hakim, jaksa, polisi dan pengacara, telah bertindak sesuai dengan persyaratan gaya moral penegakan hukum yang baik atau belum. Pengetahuan dan kepahaman masyarakat mengenai sesuatu yang baik dalam wilayah yudisial, akan dapat digunakan untuk menilai proses penyelesaian berbagai perkara yang telah atau yang masih harus diselesaikan melalui pengadilan.

Dalam proses peradilan, indikator yang dapat digunakan untuk mengamati dan memberikan tolok-ukur gaya moral penegakan hukum yang baik adalah jawaban atas pertanyaan-pertanyaan hukum, antara lain: "Adakah tindakan-tindakan kepolisian atau kejaksaan pada tingkat penyelidikan dan penyidikan telah berlangsung seperti yang diharapkan dan patut didugakan?"; "Adakah tindakantindakan polisionil demi hukum dapat dipertanggungjawabkan?"; Adakah penyelenggaraan persidangan-persidangan pengadilan, baik pada tahap dakwaan, penuntutan, maupun pada tahap penjatuhan hukuman, telah berjalan sesuai dengan ketentuan peraturan perundang-undangan?" ${ }^{27}$

Akibat dari pemahaman sebagai persoalan penegakan hukum dalam arti yang sempit, maka apabila persoalan penegakan hukum dimasukkan sebagai persoalan hukum dan peradilan, persoalannya akan disempitkan ke dalam persoalan hukum acara, mekanisme dan prosedur formal belaka. Pejabat hukum akan dinilai sudah bertindak benar apabila mekanisme dan prosedur formal telah diikuti, meski dalam maknanya yang harfiah dan sumir. Dalam arti sempit, pelaku utama yang berperan sangat menonjol dalam proses penegakan hukum itu adalah polisi, jaksa, hakim dan pengacara. Para penegak hukum ini dapat dilihat pertama-tama sebagai orang atau unsur manusia dengan kualitas, kualifikasi, dan kultur kerjanya masing-masing. Dalam pengertian demikian persoalan penegakan hukum bergantung pada aktor, pelaku, pejabat atau aparat penegak hukum itu sendiri.

Padahal, persoalan penegakan hukum adalah persoalan gaya dan moral pengelolaan proses, yang memerlukan pemahaman terhadap -maknanya yang lebih substantif. Persoalan penegakan hukum merupakan persoalan yang terkait erat 
dengan kepentingan masyarakat dalam suatu kehidupan bernegara. Dari perspektif paham demokrasi, persoalan penegakan hukum adalah persoalan public predictability, public accountability, public transparency, dan public participation.

Dalam persoalan gaya moral penegakan hukum yang baik, apabila pemahaman rule of law dimaksudkan untuk mengontrol kepatuhan prosedural para pejabat pemerintahan dan rule oflaw diletakkan sebagai norma hukum yang tertinggi (supreme), maka harus dipahami bahwa dalam rule of law itu hendak ditegakkan demi kepentingan dan dimudahkannya masyarakat memperoleh pengetahuan informatif suatu range of predictability mengenai tindakan-tindakan para pejabat penegak hukum.

Oleh karena persoalan gaya moral penegakan hukum yang baik relevan dengan kepentingan masyarakat, maka sangat diperlukan kesadaran masyarakat atas kewajiban dan hak-hak yang dimiliki untuk memantau dan menilai kinerja para pejabat penegak hukum di badan-badan eksekutif berikut para pejabat yang mengisi jajaran birokrasi, sipil atau militer, serta badan-badan legislatif dan badan-badan yudisial. Kesadaran seperti ini perlu ditumbuhkembangkan, sehingga masyarakat akan dapat mengevaluasi berdasarkan tolok-ukur yang ada. Hanya dalam kondisi demikian, hak untuk menuntut predictability, accountablity, transparency dan participation, masyarakat dapat mengevaluasi kinerja para pejabat penegak hukum dan mencegahnya dari tindakan-tindakan yang menyimpang.

Untuk menjamin adanya penegakan hukum yang baik, maka dalam pembentukan hukum (law making process) harus ditujukan untuk mencapai tegaknya supremasi hukum. Pembentukan hukum sebagai sarana mewujudkan supremasi hukum, harus diartikan bahwa hukum termasuk penegakan hukum, harus diberikan tempat sebagai instrumen utama yang akan mengarahkan, menjaga dan mengawasi jalannya pemerintahan. Penegakan hukum harus dilakukan secara sistematis, terarah dan dilandasi konsep yang jelas, dan integritas yang tinggi. Selain itu penegakan hukum harus benar-benar ditujukan untuk meningkatkan jaminan dan kepastian hukum dalam masyarakat, sehingga keadilan dan perlindungan hukum terhadap hak asasi manusia benar-benar dapat dirasakan oleh masyarakat.

Penegakan hukum yang baik, memerlukan pelaksanaan yang terarah pada proses pencapaian sasaran yang meliputi aktualisasi tata nilai yang melandasi dan menjadi acuan perilaku proses penegakan hukum, yang tertuju pada pencapaian tujuan hukum. Semua itu dikembangkan dalam rangka mewujudkan good law enforcement governance, menjaga konsistensi dengan berbagai dimensi nilai yang terkandung 
dalam konstitusi negara yang menjadi dasar eksistensi dan acuan perilaku sistem dan proses penegakan hukum yang baik. Keadaan ini telah mendorong untuk dilakukannya harmonisasi hukum dan harmonisasi penegakan hukum secara terintegrasi, konsisten dan taat asas.

\section{Harmonisasi Hukum dan Penegakannya}

Penegakan hukum dalam arti luas mencakup kegiatan untuk melaksanakan dan menerapkan hukum serta melakukan tindakan hukum terhadap setiap pelanggaran atau penyimpangan hukum. Kegiatan penegakan hukum mencakup pula segala aktifitas yang dimaksudkan agar hukum sebagai perangkat kaidah normatif yang mengatur dan mengikat para subjek hukum dalam segala aspek kehidupan bermasyarakat dan bernegara benar-benar ditaati dan sungguh-sungguh dijalankan sebagaimana mestinya. Dalam arti sempit, penegakan hukum menyangkut kegiatan penindakan terhadap setiap pelanggaran atau penyimpangan terhadap peraturan perundang-undangan. ${ }^{28}$

Penegakan hukum dapat pula dilihat sebagai institusi, badan atau organisasi dengan kualitas birokrasinya masing-masing. Dalam kaitan ini kita melihat penegakan hukum dari kacamata kelembagaan. Perspektif ini perlu dipahami secara komprehensif dengan melihat pula keterkaitannya satu sama lain serta keterkaitannya dengan berbagai faktor dan elemen yang terkait dengan hukum itu sendiri sebagai suatu sistem. Perspektif ini meniscayakan dilakukannya harmonisasi hukum dan harmonisasi penegakan hukum secara komprehensif, terintegrasi, konsisten dan taat asas.

Secara teoritis peraturan perundang-undangan merupakan suatu sistem yang tidak menghendaki dan tidak membenarkan adanya pertentangan antara unsurunsur atau bagian-bagian di dalamnya. Peraturan perundang-undangan saling berkaitan dan merupakan bagian dari suatu sistem, yaitu sistem hukum nasional. Ditinjau dari sistem hukum nasional, peraturan perundang-undangan yang harmonis dan terintegrasi menjadi sangat diperlukan untuk mewujudkan ketertiban, menjamin kepastian dan perlindungan hukum.

28 AR. Mustopadidjaja, "Reformasi Birokrasi Sebagai Syarat Pemberantasan KKN”, Makalah Seminar Pembangunan Nasional VIII, Penegakan Hukum Dalam Era Pembangunan Berkelanjutan, diselenggarakan oleh BPHN Departemen Kehakiman dan HAM, Denpasar, 14-18 Juli 2003. 
Secara praktis keterbatasan kapasitas para penegak hukum dalam memahami dan menginterpretasikan peraturan yang ada, berakibat pada terjadinya penerapan hukum yang tidak efektif. Demikian pula lemahnya koordinasi antar sektor, antar daerah, antara sektor dan daerah, serta antara pemerintah pusat dan pemerintah daerah. Berangkat dari pemikiran tersebut langkah yang harus ditempuh adalah melakukan harmonisasi sistem hukum, guna mencegah timbulnya disharmoni peraturan perundang-undangan yang pada gilirannya dapat melahirkan disharmoni dalam penerapannya.

Rudolf Stammler mengemukakan suatu konsep fungsi hukum, bahwa tujuan atau fungsi hukum adalah harmonisasi berbagai maksud, tujuan dan kepentingan antara individu dengan individu dan antara individu dengan masyarakat. Dikatakan oleh Stammler, "A just law aims at harmonizing individual purposes with that of society"..$^{29}$ Prinsipprinsip hukum yang adil mencakup harmonisasi antara maksud dan tujuan serta kepentingan perorangan, dan maksud dan tujuan serta kepentingan umum. Maksud dan tujuan serta kepentingan terdiri atas dua unsur, yaitu saling menghormati dan partisipasi. ${ }^{30}$

Harmonisasi hukum sebagai upaya atau proses penyesuaian asas dan sistem hukum, agar terwujud kesederhanaan hukum, kepastian hukum dan keadilan. Harmonisasi hukum sebagai suatu proses dalam pembentukan peraturan perundangundangan, mengatasi hal-hal yang bertentangan dan kejanggalan di antara normanorma hukum di dalam peraturan perundang-undangan, sehingga terbentuk peraturan perundang-undangan nasional yang harmonis, dalam arti selaras, serasi, seimbang, terintegrasi dan konsisten, serta taat asas. ${ }^{31}$

Langkah sistemik harmonisasi hukum nasional, bertumpu pada paradigma Pancasila dan UUD 1945 yang melahirkan sistem ketatanegaraan dengan dua asas fundamental, asas demokrasi dan asas negara hukum yang diidealkan mewujudkan sistem hukum nasional dengan tiga komponen, yaitu substansi hukum, struktur hukum beserta kelembagaannya, dan budaya hukum. Langkah sistemik tersebut di satu sisi dapat dijabarkan dalam harmonisasi peraturan perundang-undangan dan di sisi lain diimplementasikan dalam rangka penegakan hukum. ${ }^{32}$

\footnotetext{
${ }^{29}$ Hari Chand, Modern Jurisprudence, International Law Book Services, Kuala Lumpur, 1994, hlm. 49.

30 Theo Huijbers, Filsafat Hukum Dalam Lintasan Sejarah, Kanisius, Yogyakarta, 1995, hlm.150-155.

${ }^{31}$ Kusnu Goesniadhie S., Harmonisasi Hukum Dalam Perspektif Perundang-undangan, Lex Specialis Suatu Masalah, JPBooks, Surabaya, 2006, hlm. 291-294.

${ }^{32}$ Ibid.
} 
Melalui harmonisasi hukum, akan terbentuk sistem hukum yang mengakomodir tuntutan akan kepastian hukum dan terwujudnya keadilan. Begitu pula dalam hal penegakan hukum, harmonisasi hukum akan dapat menghindari tumpang tindih bagi badan peradilan yang melakukan kekuasaan kehakiman, dengan badan-badan pemerintah yang diberi wewenang melakukan fungsi peradilan menurut peraturan perundang-undangan.

Dasar dan orientasi dalam setiap langkah harmonisasi hukum adalah tujuan harmonisasi, nilai-nilai dan asas hukum, serta tujuan hukum itu sendiri, yakni harmoni antara keadilan, kepastian hukum dan sesuai tujuan (doelmatigheid). Pada akhirnya, pelaksanaan penegakan hukum perlu memperhatikan aktualisasi tata nilai yang terkandung dalam konstitusi dan prinsip-prinsip penegakan hukum yang baik (good law enforcement governance).

Harmonisasi hukum memiliki fungsi pencegahan dan fungsi penanggulangan terjadinya disharmoni hukum. Harmonisasi hukum untuk mencegah terjadinya disharmoni hukum memerlukan teknik-teknik penemuan hukum dalam rangka mempertegas kehendak hukum, kehendak masyarakat dan kehendak moral. Harmonisasi hukum yang bersifat pencegahan dilakukan dalam rangka mengantisipasi kenyataan tentang adanya faktor-faktor potensial yang dapat menyebabkan terjadinya disharmoni hukum. Dengan demikian harmonisasi hukum merupakan kegiatan penemuan kehendak hukum, kehendak masyarakat dan kehendak moral melalui kegiatan penafsiran hukum dan penalaran hukum, serta pemberian argumentasi yang rasional terhadap hasil penafsiran dan penalaran hukum. ${ }^{33}$

Dalam menuju penegakan hukum yang baik, harmonisasi hukum harus dapat mencerminkan keterpaduan dalam penerapan peraturan perundang-undangan, yang terdiri atas mekanisme pengaturan, administrasi pengaturan, antisipasi terhadap perubahan, dan sebaliknya di dalam keterpaduan tersebut juga tercermin harmonisasi penegakan hukum. Aspek hukum dan kelembagaan (legal and institutional aspects) dalam penegakan hukum yang baik, diwujudkan dalam bentuk harmonisasi interaksi penegakan hukum antar kelembagaan. Oleh karena interaksi penegakan hukum dan kelembagaan terjadi di setiap komponen kegiatan dan juga antar komponen kegiatan, maka keterpaduan tersebut harus diupayakan untuk terwujud di setiap tingkatan

${ }^{33}$ Kusnu Goesniadhie S., Harmonisasi Sistem Hukum Mewujudkan Tata pemerintahan Yang Baik, Penerbit A3, Malang, 2009, hlm. 11. 
penegakan hukum dan kelembagaan. Apabila keterpaduan hukum dapat diwujudkan, maka keterpaduan dalam aplikasinya juga harus selalu menuju penegakan hukum yang baik. Keterpaduan kelembagaan senantiasa akan menjadi jaminan bagi terselenggaranya harmonisasi dalam penegakan hukum yang baik (good law enforcement governance).

\section{Penutup}

Dalam studi ini konsep 'good governance' dipahami dan diterapkan sebagai kerangka konsep penegakan hukum, maka secara teoritis dikenal konsep 'good law enforcement governance', dalam pengertian kerangka konsep' penegakan hukum yang baik' derivasi dari konsep 'good governance'.

Good law enforcement governance, diterjemahkan sebagai 'seni atau gaya moral penegakan hukum yang baik', lebih mengacu pada the manner, memerlukan suatu butir-butir moral-legal dalam pelaksanaannya.

Penegakan hukum yang baik, memerlukan pelaksanaan yang terarah pada proses pencapaian sasaran yang meliputi aktualisasi tata nilai yang melandasi dan menjadi acuan perilaku proses penegakan hukum, yang tertuju pada pencapaian tujuan hukum.

Aspek hukum dan kelembagaan (legal and institutional aspects) dalam penegakan hukum yang baik, diwujudkan dalam bentuk harmonisasi interaksi penegakan hukum antar kelembagaan.

Harmonisasi interaksi penegakan hukum antar kelembagaan terjadi di setiap komponen kegiatan dan juga antar komponen kegiatan, maka keterpaduan tersebut harus diupayakan untuk terwujud di setiap tingkatan penegakan hukum dan kelembagaan.

Apabila harmonisasi hukum dapat diwujudkan, maka keterpaduan dalam aplikasinya juga harus selalu menuju pada penegakan hukum yang baik. Keterpaduan antar kelembagaan senantiasa akan menjadi jaminan bagi terselenggaranya harmonisasi dalam penegakan hukum yang baik (good law enforcement governance). 


\section{Daftar Pustaka}

Apeldoorn, L.J. van, Pengantar Ilmu Hukum, Pradnya Paramita, Jakarta, 1983.

AR., Mustopadidjaja, "Reformasi Birokrasi Sebagai Syarat Pemberantasan KKN", Makalah Seminar Pembangunan Nasional VIII, Penegakan Hukum Dalam Era Pembangunan Berkelanjutan, diselenggarakan oleh BPHN Departemen Kehakiman dan HAM, Denpasar, 14-18 Juli 2003.

Bogdan, Robert, and Steven J. Taylor, Introduction to Qualitative Research Methods, John Wiley \& Sons, New York, 1975.

Burhanuddin, Etika Individual Pola Dasar Filsafat Moral, Rineka Cipta, Jakarta,1997.

Chand, Hari, Modern Jurisprudence, International Law Book Services, Kuala Lumpur, 1994.

Collinson, Diane, Fifty Major Philosophers, (terj. Ilza mudin Ma'mur dan Mufti Ali, Lima Puluh Filosof Dunia Yang Menggerakkan), Raja Grafindo, Jakarta, 2001.

Code of Conduct for Law Enforcement Officials, Adopted by General Assembly Resolution 34/169 of 17 December 1979.

Curzon, L.B., Jurisprudence, W \& E Handbook, 1979.

Encyclopedia International, Grolier Incorporated, New York, 1967, (6).

Europa Union International Commission, Web.http:/wwww.europa.eu.int/comm/governance/

Garner, Bryan A., Black's Law Dictionary, St. Paul Minn, West Group, 1999.

GoesniadhieS., Kusnu, Harmonisasi Hukum Dalam Perspektif Perundang-undangan, Lex Specialis Suatu Masalah, JPBooks, Surabaya, 2006.

, Harmonisasi Sistem Hukum Mewujudkan Tata pemerintahan Yang Baik, Penerbit A3, Malang,2009.

Graham, John, and Bruce Amos and Tim Plumptre, Institute On Governance (IOG: 2003), Canada, dalam Principles for Good Governance in the 21st Century, Web. http://www.iog.ca/publications/policy

Huijbers, Theo, Filsafat Hukum Dalam Lintasan Sejarah, Kanisius, Yogyakarta, 1995.

Kusumohamidjojo, Budiono, Ketertiban Yang Adil Problematik Filsafat Hukum, Gramedia Widiasarana Indonesia, Jakarta, 1999.

Liputo, Yuliani, (ed.), Kamus Filsafat, Remaja Rosdakarya, Bandung, 1995.

Locke, John, The Secon Treaties of Government, Stuttgart, Reclam, 1980.

New Webster Dictionary of the English Language, Grolier Incorporated, New York, 1970.

Reksodiputro, Mardjono, "Reformasi Hukum di Indonesia", Seminar Hukum Nasional Ke VII, BPHN Departemen Kehakiman dan HAM, 1999. 
Porter, Julia, Sustainability and good governance: Monitoring participation and process as well as outcomes, 2002, Website, http://www.porteradelaide/

Sahgal, Vinod, and Deepa Chakrapani, Clean Government and Public Financial Accountability, Washington, D.C., The World Bank, 2000.

Soekanto, Soerjono, Beberapa Permasalahan Hukum Dalam Kerangka Pembangunan di Indonesia, UI-Press, Jakarta, 1983.

Wignjosoebroto, Soetandyo, "Hukum dan Moral Pemerintahan yang Baik", Jurnal Analisis Hukum 2002, Jangan Tunggu Langit Runtuh, Jakarta, hukumonline.com. 
